\title{
Noise of Motor Vehicles at from of Baiturrahman Great Mosque Semarang City
}

\author{
Syaiful, Sri Wiwoho Mudjanarko \\ Civil Engineering Departement Ibn Khaldun University Bogor, INDONESIA \\ Civil Engineering Departement Narotama University Surabaya, INDONESIA \\ syaiful@ft.uika-bogor.ac.id
}

\begin{abstract}
Research done by the field survey data collection a good number of motor vehicles, the number of motorcycles, the number of general passenger cars and goods by measuring the level of noise generated by the modes of transport. The relationship between the noise generated by the distance of sound sources can be displayed as follows: $y=$ $46,286+0,0483 \times 2+0,00065 \times 3+0,00180 \times 4$ means a distance of 56,35 meters of $53,26 \mathrm{~dB}_{\mathrm{A}}$ noise level.
\end{abstract}

Key words : Noise level, speed, volume, sound source distance.

\begin{tabular}{|c|c|c|}
\hline Received & Revised & Published \\
\hline 11 January 2019 & 17 February 2019 & 30 March 2019 \\
\hline
\end{tabular}

\section{INTRODUCTION}

The city of Semarang is the capital of Central Java Province, is one of the big cities with densely populated population in Indonesia. The increase in transportation modes from year to year continues to increase (Semarang, 2015). Public and private transport transportation activities also develop. Transportation problems in the city of Semarang are influenced by the number of modes of transportation which are increasing every year and population growth increases with the increase in income of the urban population (Semarang, 2001). Motorized vehicles have the potential to add more noise than no vehicle at all and can be solved using noise calculations (Syaiful, 2017a,2015b).

The purpose of the study was to determine the level of noise caused by motorized vehicles to traffic flow with the speed and volume of motorized vehicles in the complex of Baiturrahman Great Mosque Semarang City. The benefits of the study are expected to be an input for the Semarang city government in developing and organizing the Baiturrahman Great Mosque in Semarang which is more comfortable/noisy, more organized, clean and orderly. Research limits 


\section{THE SPIRIT OF SOCIETY JOURNAL}

International Joumal of Society Development and Engagement

ISSN : 2597-4777 (Online) - ISSN : 2597-4742 (Print)

This work is licensed under a Creative Commons Attrib ution- ShareAlike 4.0 International License.

are needed as a source of noise caused by motorized vehicles, both passenger public transport and private goods and vehicles and motorbikes in front of the Semarang Baiturrahman Great Mosque complex. Inside the Baiturrahman Great Mosque in Semarang is a school namely Isriati Islamic Elementary School, a fence made of iron with a height of 1,60 m, and a distance of 17,65 meters from the roadside of the Simpang Lima area to the north west of Pandanaran road. The location of the nearest Baiturrahman Mosque building is 56,35 meters from the edge of the road.

\section{LITERATURE REVIEW}

\section{Understanding of the wind}

Winds arise due to differences in air temperature due to solar radiation, resulting in a difference in air pressure. Wind measurements in the field must be carried out over a long period of time while measuring instruments to determine the wind speed of the placement must be free of obstructions with a radius of twenty meters (UI, 1997).

\section{Land use}

Land use in a city is closely related to the existing transportation mode. According to Warpani (1997) in general, transportation can be seen as a system with 3 (three) components that influence each other, namely:

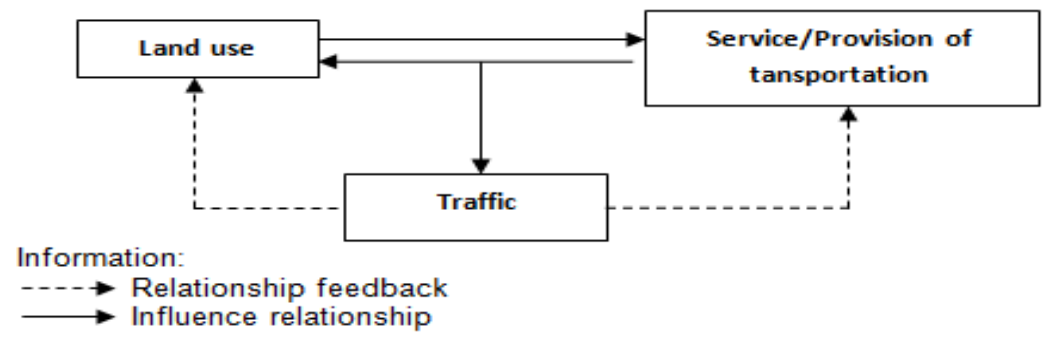

Figure 1 Interaction of land use and transportation services/provision 


\section{THE SPIRIT OF SOCIETY JOURNAL}

International Joumal of Society Development and Engagement

ISSN : 2597-4777 (Online) - ISSN : 2597-4742 (Print)

This work is licensed under a Creative Commons Attrib ution-ShareAlike 4.0 International License.

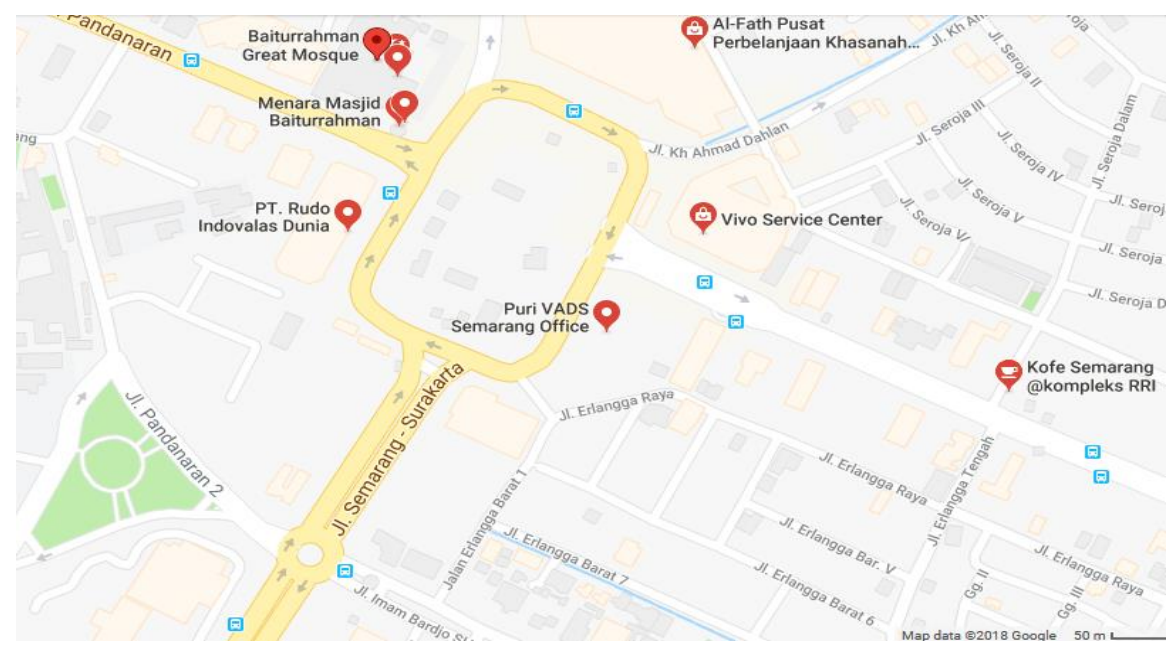

Figure 2 Research sites

Source:https://www.google.com/search?safe=strict\&client=firefox$\underline{b} \& \mathrm{q}=$ komplek+masjid+baiturrahman+semarang\&npsic=0\&rflfq $=1 \& \mathrm{rlha}=0 \& \mathrm{rllag}=-$ 6987157,110416044,727\&tbm=lcl\&ved=2ahUKEwiW NDG3eTcAhXHdisKHfGMC7EQtgN6BAg AEAQ\&tbs=Irf:!2m1!1e2!2m1!1e3!3sIAE,If:1, If ui:2\&rldoc=1\#rlfi=hd:;si:;mv:!1 m3!1d2624.632930 577808!2d110.42378084034817!3d-6.9912039708715135!3m2!1i946!2i509!4f13.1 [1].

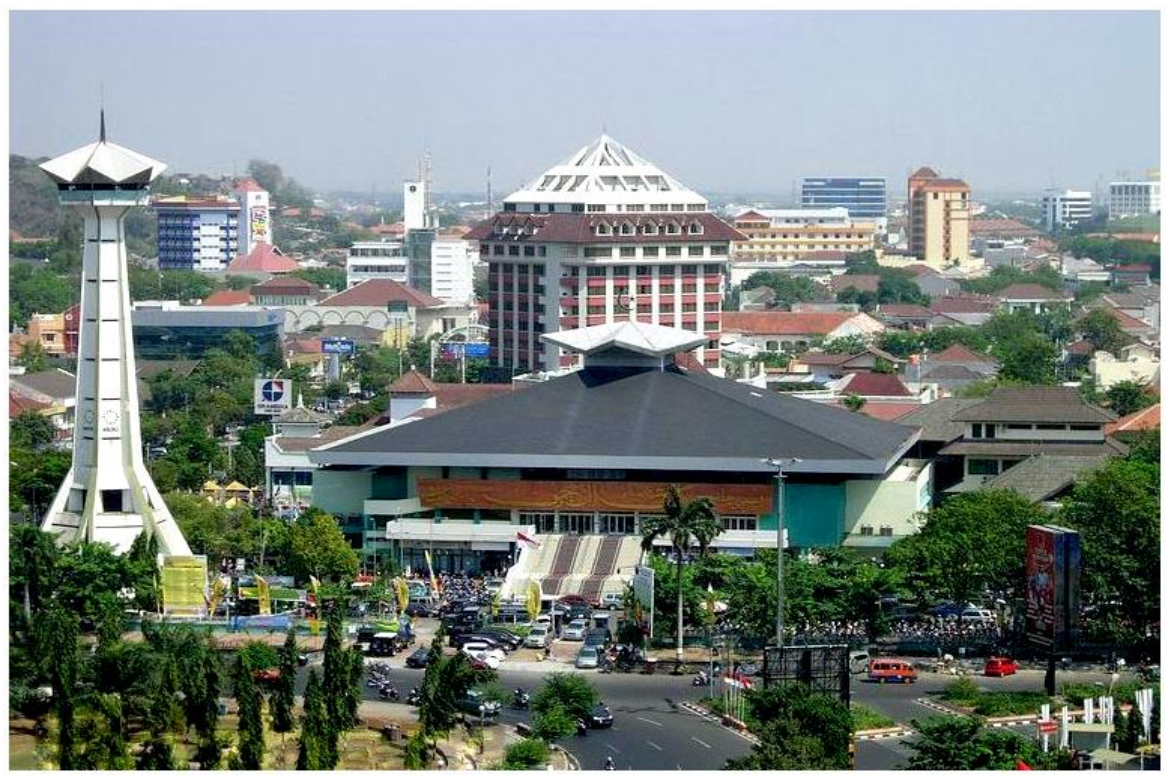

Figure 3 Seen in front of the research location in front of Baiturrahman Great Mosque in Semarang

Source:

Noise of Motor Vehicles at from of Baiturrahman Great Mosque Semarang City 


\section{THE SPIRIT OF SOCIETY JOURNAL}

International Joumal of Society Development and Engagement

ISSN : 2597-4777 (Online) - ISSN : 2597-4742 (Print)

This work is licensed under a Creative Commons Attrib ution-ShareAlike 4.0 International License.

https://id.wikipedia.org/w/index.php?title=Berkas:Masjid Baiturrahmanb.jpeg\&filetimestamp=20 151022105931\& [2].

\section{Understanding noise, about sound and hearing}

Noise is measured by making local measurements along the road in normal traffic conditions with $\mathrm{dB}_{\mathrm{A}}$ measurement units. Noise due to traffic ranges from $60-80 \mathrm{~dB}_{\mathrm{A}}$.

Table 1 Effect of noise

\begin{tabular}{llccc}
\hline No & Description & Noise effect & Desibell & Example \\
\hline 1. & Cause & Deaf & 150 & Explosion \\
& accidents & Pain & 140 & Machine testing \\
& & Threshold & 120 & Thunder, gunfire \\
& & Feeling & 110 & Wind drill, airplane \\
\hline 2. & Interference & & 100 & Subway \\
& & Work efficiency reduction & 90 & \\
& Ear function disorders & 85 & Traffic congested roads \\
& & 80 & Noisy factory, Noisy office \\
& \multirow{2}{*}{ Normal speech disorder } & 70 & Train on the edge of the \\
& & 65 & city \\
& & 60 & Factory \\
\hline
\end{tabular}

Source: Fundamentals of transportation engineering [10].

\section{Sound effects}

Sound is an energy that occurs because of vibration. Characteristics of sound are intensity, hardness, frequency and sharpness. Speaking comfortably normally sounds between 40 to 65 desiBell scale $A$.

Here is the intensity of human hearing and the level of intensity of the environment and situation.

Table 2 Noise levels in the activity environment Noise of Motor Vehicles at from of Baiturrahman Great Mosque Semarang City 


\begin{tabular}{lc}
\hline No $\quad$ Area Allotment & Noise Level (dBA) \\
\hline 1. Area designation & 55 \\
Housing and settlements & 70 \\
Trade and services & 65 \\
Offices and trade & 50 \\
Open living space & 70 \\
$\quad$ Industry & 60 \\
Government and public facilities & 70 \\
Recreation & 70 \\
Port & 60 \\
Nature preserve & 55 \\
& 55 \\
2. Activity environment & 55 \\
Hospital or the like & School or the like \\
Places of worship or the like &
\end{tabular}

Source: Quality standards for noise levels for an area or environmental activity (Goverment, 1996).

\section{Side effects of noise on hearing}

The auditory physiology is that one can hear through vibrations that are passed through the air or bone directly to the cochlea (Iskandar, 1993).

Acoustic trauma or noise exposure is often used to express deafness due to noise exposure, as well as sudden hearing loss due to severe explosions, booms, gun shots and trauma directly to the ear or head. Much has been learned about noise and deafness caused by persistent noise, our knowledge of the adverse effects of noisy hammer clashes or the like on hearing is very limited $[(U I, 1997)$.

\section{METHOD}

\section{Location and place of research}

The location of this research was conducted in front of the area of the Baiturrahman Great Mosque in Semarang City. Types of motorized vehicles recorded are:

Types of motorized vehicles are motorbikes, sedans, types of jeeps, types of minibuses, types of trucks, types of buses and types of truck trailers and large tank trucks both oil and clean and dirty water tanks, all motorized vehicles that pass in front of the area Baiturrahman Great Mosque in Semarang City.

\section{The equipment used includes:}




\section{THE SPIRIT OF SOCIETY JOURNAL}

International Joumal of Society Development and Engagement

ISSN : 2597-4777 (Online) - ISSN : 2597-4742 (Print)

This work is licensed under a Creative Commons Attrib ution-ShareAlike 4.0 International License.

The tools used are four hand tally counters, a set of stationery and a data entry form and a computer set.

\section{The personnel involved are:}

The personnel involved were, requiring four surveyors, local personnel and computer operators with a working period of three days.

\section{Collection of primary data in front of Baiturrahman Great Mosque}

Data collection on the number of vehicles passing in front of the Baiturrahman Great Mosque in Semarang City.

The vehicles that were recorded were the types of vehicles, motorbikes, private vehicles, micro buses, buses, pick ups, micro trucks, trucks with two axles. Except for non-motorized vehicles, crushing machines, military vehicles, convoys of hearses, the activities were carried out for 12 hours starting from $06.00-18.00$ WIB. At this point is a distance of 0,00 meters right on the edge of the road, a distance of 9.00 meters on the edge of the sidewalk and a distance of 56,35 meters near the east side of the Baiturrahman Great Mosque building.

\section{Composition and speed of traffic flow}

Data collection starts at $06.00-18.00$ WIB for 12 hours, except on Sunday data collection starts at $09.00-18.00 \mathrm{WIB}$.

\section{Measure distance with sound source.}

a. Measuring SPL (Sound Pressure Level) means measuring the sound source level from distance $=0,00$ meters (highway edge). The Rion brand NA-24 sound level meter has been calibrated with approval calibrator tools number 2G-391-O brand Quest technologies (94 $\mathrm{dBA}$ ), placed at a measurement location on the edge of the highway, this tool is faced with a source of noise / perpendicular to the road highway, observed every three minutes for sixty minutes each observation and activities carried out for 12 hours.

b. Measuring SPL (Sound Pressure Level) from a distance $=9,00$ meters (above the sidewalk).

c. Measuring SPL (Sound Pressure Level) from a distance $=56,35$ meters (on the outside of the mosque wall, the farthest distance).

\section{Research flow chart}

The research flow chart is as follows: 


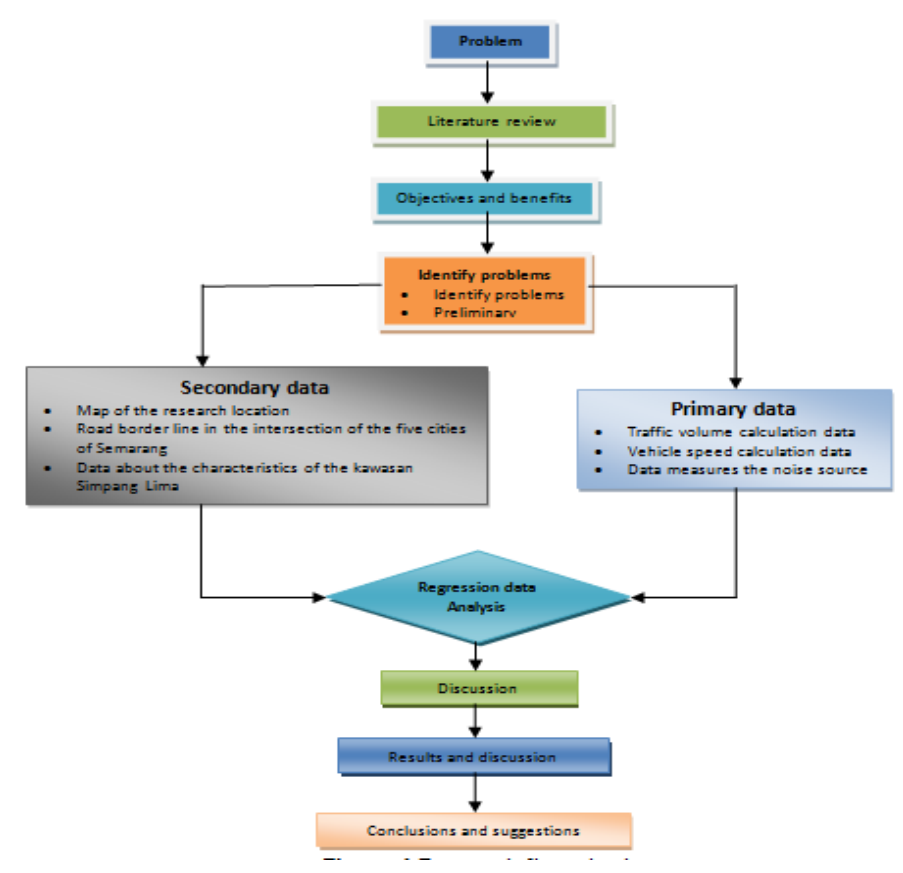

Figure 4 Research flow chart

\section{Data collection technique}

The number of 30 samples above is searched descriptively namely the mean and standard deviation:

Mean

$\mathrm{n}$

$$
\sum f x
$$$$
=
$$

30
19,20

$$
=
$$

Standar deviasi

$$
\begin{aligned}
& \left.\left.\mathrm{n}\left(\left(\sum f \times 2\right)-\sum f \mathrm{x}\right)\right) \quad((30.14,80)-19,20)\right) \\
& \quad=\mathrm{V} \frac{\mathrm{n}(\mathrm{n}-1)}{}=\mathrm{V} \frac{30(30-1)}{\quad} \frac{0,2943}{}
\end{aligned}
$$

Sampling error can be accepted if:

Acceptable sampling error $=0,05$. Average number mean 


$$
\begin{aligned}
& =0,05 \times 0,640 \\
& =0,0320
\end{aligned}
$$

Standart error can be accepted if:

Acceptable standart error se. $(x) \quad=0,0320 / 1,96$

$$
=0,0163
$$

The number of samples needed is:

$$
\begin{aligned}
& \text { S2 } \quad(0,2943) 2 \\
& \text { (S.e.(x))2 } \quad(0,0163) 2 \\
& =325,99=330 \text { sample }
\end{aligned}
$$

The number of samples needed to represent respondents who visited the Baiturrahman Great Mosque in Semarang City was set to 330 samples. The survey conducted at the beginning of the study has obtained as many as 30 samples from respondents, then an additional 300 samples are needed. The reason is that according to survey data will be calculated the amount of data that 330 samples are needed in order to fulfill the statistical calculation and can represent the total amount of data that will represent it.

\section{Assuming the amount of data}

The assumption taken is that the noise level increase ( $y)$ is an independent variable and is influenced by several independent variables, namely:

$\mathrm{x} 1$ is the first independent variable/motorcycle speed (SPM)

$\mathrm{x} 2$ is the second independent variable/passenger car speed (MP)

$x 3$ is the third independent variable/motorcycle volume (SPM)

$\mathrm{x} 4$ is the fourth independent variable/passenger car volume (MP)

Based on the data above, a linear regression model approach is obtained:

$y=a 0+a 1 \cdot x 1+a 2 \cdot x 2+a 3 \cdot x 3+a 4 \cdot x 4+$ an.xn

\section{RESULTS AND DISCUSSION}

\section{Results}

Based on the variables that have been discussed, the results of the data processing are shown, which are three equations, namely:

a. Distance of 0,00 from the highway. 


\section{THE SPIRIT OF SOCIETY JOURNAL}

International Joumal of Society Development and Engagement

\begin{tabular}{|c|c|c|c|c|c|c|c|}
\hline $\begin{array}{l}\mathbf{N} \\
\mathbf{O}\end{array}$ & $\begin{array}{c}\text { Variabl } \\
\text { e }\end{array}$ & $\mathbf{R}$ & $\mathbf{R}^{2}$ & $\begin{array}{c}\text { Std } \\
\text { Erro } \\
r\end{array}$ & $\mathbf{F}$ & t hit & Equation \\
\hline 1 & $x 1, x 3$ & $\begin{array}{l}0,64 \\
0\end{array}$ & $\begin{array}{l}0,41 \\
0\end{array}$ & $\begin{array}{l}0,34 \\
1\end{array}$ & $\begin{array}{l}6,23 \\
5\end{array}$ & $\begin{array}{l}1,93 \\
6\end{array}$ & $y=53,792+0,297 \times 1+0,00523 \times 3$ \\
\hline 2 & $x 1, x 3, x 4$ & $\begin{array}{l}0,61 \\
8\end{array}$ & $\begin{array}{l}0,38 \\
2\end{array}$ & $\begin{array}{l}0,26 \\
6\end{array}$ & $\begin{array}{l}4,82 \\
0\end{array}$ & $\begin{array}{l}1,87 \\
8\end{array}$ & $\begin{array}{l}y=53,624+0,294 \times 1+0,0087 \times 3+0,0067 \\
x 4\end{array}$ \\
\hline 3 & $x 4$ & $\begin{array}{l}0,61 \\
3\end{array}$ & $\begin{array}{l}0,37 \\
8\end{array}$ & $\begin{array}{l}0,34 \\
3\end{array}$ & $\begin{array}{l}5,28 \\
8\end{array}$ & $\begin{array}{l}4,15 \\
8\end{array}$ & $y=63,893+0,00040 x 4$ \\
\hline
\end{tabular}

The statistical analysis above is the correlation coefficient $>0,60$ because based on the table above that the value above 0,60 the data produced is very good the level of accuracy is:
Obtained t test (count)
$=1,936$
$>\mathrm{t}$ tabel $=1,725$ (fulfilled)

So we will get the following equation:

$y=53,792+0,297 \times 1+0,00523 \times 3$

b. Distance 9,00 from the highway.

\begin{tabular}{|c|c|c|c|c|c|c|c|}
\hline No & Variable & $\mathbf{R}$ & $\mathbf{R}^{2}$ & $\begin{array}{c}\text { Std } \\
\text { Erro } \\
r\end{array}$ & $\mathbf{F}$ & t hit & Equation \\
\hline 1 & $x 1, x 2, x 3$ & $\begin{array}{l}0,64 \\
3\end{array}$ & $\begin{array}{l}0,41 \\
3\end{array}$ & $\begin{array}{l}2,45 \\
6\end{array}$ & $\begin{array}{l}5,18 \\
7\end{array}$ & 1,576 & $\begin{array}{l}y=43,018+0,248 \times 1+0,00379 \times 2+0,0 \\
03305 \times 3\end{array}$ \\
\hline 2 & $x 2, x 3, x 4$ & $\begin{array}{l}0,56 \\
2\end{array}$ & $\begin{array}{l}0,31 \\
6\end{array}$ & $\begin{array}{l}2,09 \\
3\end{array}$ & $\begin{array}{l}2,45 \\
9\end{array}$ & 0,672 & $\begin{array}{l}y=16,1981,510 \times 2+0,00375 \times 3+0,00 \\
579 \times 4\end{array}$ \\
\hline 3 & $\begin{array}{l}x 1, \times 2, x 3, \\
x 4\end{array}$ & $\begin{array}{l}0,67 \\
2\end{array}$ & $\begin{array}{l}0,45 \\
1\end{array}$ & $\begin{array}{l}3,39 \\
3\end{array}$ & $\begin{array}{l}5,82 \\
5\end{array}$ & 2,140 & $\begin{array}{l}y=4,672+0,320 \times 1+1,538 \times 2+0,0037 \\
5 \times 3+0,00579 \times 4\end{array}$ \\
\hline
\end{tabular}

The resulting data is very good at the level of accuracy, namely:

Obtained t test (count) $\quad=7,088 \quad>t$ tabel $=1,725$ (fulfilled)

So we will get the following equation:

$y=4,672+0,320 \times 1+1,538 \times 2+0,00375 \times 3+0,00579 \times 4$

c. The longest distance is 56,35 from the highway.

\begin{tabular}{llllllll}
\hline No & Variable & $\mathbf{R}$ & $\mathbf{R}^{2}$ & $\begin{array}{l}\text { Std } \\
\text { Erro } \\
\mathbf{r}\end{array}$ & $\mathbf{F}$ & $\mathbf{t}$ hit & Equation \\
\hline 1 & $\times 2, \times 3$ & 0,64 & 0,42 & 2,37 & 6,16 & 5,934 & $\mathrm{Y}=49,707+0,456 \times 2+0,00092 \times 3$ \\
& 8 & 0 & 7 & 0 & & \\
\hline
\end{tabular}




\section{THE SPIRIT OF SOCIETY JOURNAL}

International Joumal of Society Development and Engagement

ISSN : 2597-4777 (Online) - ISSN : 2597-4742 (Print)

This work is licensed under a Creative Commons Attrib ution-ShareAlike 4.0 International License.

\begin{tabular}{llllllll}
\hline $\mathbf{2}$ & $\mathbf{x 2 , \times 3 , \times 4}$ & $\mathbf{0 , 6 4}$ & $\mathbf{0 , 4 1}$ & $\mathbf{1 , 0 9}$ & $\mathbf{4 , 8 1}$ & $\mathbf{4 , 1 7 1}$ & $\mathrm{Y}=\mathbf{4 6 , 2 8 6 + 0 , 0 4 8 3 \times 2 + 0 , 0 0 6 5 \times 3 + 0 ,}$ \\
& & $\mathbf{5}$ & $\mathbf{6}$ & $\mathbf{7}$ & $\mathbf{7}$ & & $\mathbf{0 0 1 8 0 \times 4}$ \\
\hline 3 & $\times 2, \times 4$ & 0,63 & 0,40 & 0,87 & 5,09 & 4,234 & $\mathrm{Y}=46,018+0,486 \times 2+0,00290 \times 4$ \\
& & 4 & 2 & 0 & 8 & & \\
\hline
\end{tabular}

The resulting data is very good at the level of accuracy, namely:

Obtained $\mathrm{t}$ test (count) $\quad=4,171 \quad>\mathrm{t}$ tabel $=1,725$ (fulfilled)

So we will get the following equation:

$y=46,286+0,0483 \times 2+0,0065 \times 3+0,00180 \times 4$

\section{DISCUSSION}

1) The equation $y=53,792+0,297 \times 1+0,00523 \times 3$ for a distance of 0,00 meters from the highway is $77,90 \mathrm{dBA}$ without a barrier.

2) The equation $y=4,672+0,320 \times 1+1,538 \times 2+0,00375 \times 3+0,00579 \times 4$ for a distance of 9,00 meters from the highway is $68,17 \mathrm{dBA}$ without a barrier.

3) The equation $y=46,286+0,0483 \times 2+0,0065 \times 3+0,00180 \times 4$ for the farthest distance of 56,35 meters from the highway is $53,26 \mathrm{dBA}$ with a fence and tree barrier.

\section{CONCLUSION}

1) This study shows that the study of noise caused by motor vehicle noise is significant to the distance from the sound source. The farthest distance from the sound source is 56.35 meters (the farthest distance / on the east side of the Great Baiturrahman Mosque building) having a noise level of $53,26 \mathrm{dBA}$ means that it is in line with the standards permitted by the Semarang City Bapedalda which is $60 \mathrm{dBA}$.

2) If examined further about the distance relationship with the level of noise is the equation that shows the relationship of distance to the source of sound: $y=46,286+0,0483 \times 2+0,0065 \times 3$ $+0,00180 \times 4$ means that the farther the distance from the sound source the lower the level noise

\section{REFERENCES}

Government of the Republic of Indonesia Decree of the Minister of Environment No.48,1996, Quality Standards for Noise Level for an Area or Activity Environment, KLH Publisher, Jakarta.

https://www.google.com/search?safe=strict\&client=firefox-

$\underline{b} \& \mathrm{q}=$ komplek + masiid + baiturrahman + semarang\&npsic $=0 \&$ rflfq $=1 \&$ rlha $=0 \&$ rllag $=-$

6987157,110416044,727\&tbm=lc|\&ved=2ahUKEwiW NDG3eTcAhXHdisKHfGMC7EQtgN6 BAgAEAQ\&tbs=Irf:!2m1!1e2!2m1!1e3!3s|AE,If:1, If ui:2\&rldoc=1\#rlfi=hd:;si:;mv:!1 m3!1d262 


\section{THE SPIRIT OF SOCIETY JOURNAL}

International Joumal of Society Development and Engagement

ISSN : 2597-4777 (Online) - ISSN : 2597-4742 (Print)

This work is licensed under a Creative Commons Attrib ution-ShareAlike 4.0 International License.

\section{$\underline{4.632930577808 ! 2 \mathrm{~d} 110.42378084034817 ! 3 \mathrm{~d}-}$}

6.9912039708715135!3m2!1i946!2i509!4f13.1

https://id.wikipedia.org/w/index.php?title=Berkas:Masjiid Baiturrahmanb.jpeg\&filetimestamp=

20151022105931\&

Iskandar, N., Soepardi, E. A., (1993), Ear, Nose-Throat, FKUI Publisher, Jakarta.

Semarang City Government, (2005), Semarang City in Figures, City Government Publishers, Semarang.

Semarang City Government, (2001), Road Information in Semarang City, City Government Publisher, Semarang.

Syaiful, Syaiful. (2017) Engineering model of traffic and transportation safety with pattern of cooperation between sustainable region in Bogor, MATEC Web Conf., 138 (2017) 07008

DOI: https://doi.org/10.1051/matecconf/201713807008

SYAIFUL, Syaiful; ELVIRA, (2017) Yena. Case Study On Use Area Parking At New Market City Shopping Center Bogor. IJTI (International Journal Of Transportation And Infrastructure), (S.I.), v. 1, n. 1, p. 34-40, sep. 2017. ISSN 2597-4769. Available at:

$<$ http://jurnal.narotama.ac.id/index.php/ijt/article/view/330>. Date accessed: 25 jan. 2018. doi: https://doi.org/10.29138/ijti.v1i1.330.

SYAIFUL, SYAIFUL (2005) ANALISIS KEBISINGAN ARUS LALU LINTAS DAN GEOMETRI JALAN DI KAWASAN SIMPANG LIMA KOTA SEMARANG. Masters thesis, program Pascasarjana Universitas Diponegoro. Diponegoro University, INSTITUTIONAL REPOSITORY. (Indonesian Language)

Lecturer Staff of FK UI, (1997), Ear, Nose, Throat, Head and Neck Disease, Aksara Binarupa Publisher, Jakarta, Volume Two.

Teaching Staff of FT UNDIP, (1983), Situation of Wind Energy and Its Potential in Indonesia, Research Institute of Diponegoro University, Semarang.

Teaching Staff of FT UNDIP, (2001), Fundamentals of Transportation Engineering, UNDIP Publisher, 2001

Warpani Suwardjoko, (1990). Planning the Transportation System, Publisher of Bandung Institute of Technology, Bandung. 